\title{
Use of Information and Communication Technologies by Extension Personnel to Disseminate Agricultural Information
}

\author{
Noor Agha, B.S. Ghanghas" and P.K. Chahal \\ Department of Extension Education, CCS Haryana Agricultural University, \\ Hisar-125004, Haryana, India \\ *Corresponding author
}

\begin{tabular}{|c|}
\hline Keywords \\
\hline $\begin{array}{l}\text { Extension } \\
\text { Personnel, ICT, } \\
\text { Constraints and } \\
\text { consequences }\end{array}$ \\
\hline Article Info \\
\hline $\begin{array}{l}\text { Accepted: } \\
12 \text { March } 2018 \\
\text { Available Online: } \\
10 \text { April } 2018\end{array}$ \\
\hline
\end{tabular}

Keywords

Extension

Personnel, ICT,

Constraints and consequences

10 April 2018

\section{A B S T R A C T}

India has been experiencing major changes in agricultural extension system since the beginning of the $21^{\text {st }}$ century. The reforms included both demand and supply side measures. Information and Communication Technology (ICT) has become a global tool often used by individuals, organizations, governments and inter-governmental organizations for personal or official activities. Its application cut across all fields of human endeavor like medicine, commerce, engineering, architecture, education, library services, and agriculture. Information and communications technologies have been of great significance in the development agenda of most countries. Information and communications technologies have been of great significance in the agricultural development agenda of most countries due to their critical role in facilitating socioeconomic development of farming community. This is because it involves a shift from the traditional resource based method of production to a new science based method and commercialization of agriculture in digital world. The findings indicated that majority of the extension personnel used mobile phone to seek farmers' participation and to deliver timely extension \& advisory services to stakeholders, more than 80.00 percent and about 60.00 per cent of the respondents used most popular social media like Whats App and facebook for extension activities respectively. The less knowledge of farmers about ICTs and lack of specialized trainings received on ICTs by field functionaries were very serious constraints in use of these tools. Loss of competitiveness, loss of contact with timely information and loss of extension management efficiency were the major consequences/concerns perceived by field functionaries for not using the ICTs presently or in near future.

\section{Introduction}

The Information and Communication Technology (ICT) is not only one of the driving forces of globalization but it played important role in liberalization of world trade in the field of agriculture responsible for agripreneurship development across the world.
Integration of ICT is rapidly transforming the way of agricultural technology transfer. The ICT enabled extension systems are acting as a key agent for changing agrarian situation and farmers' lives by improving access to reliable, timely and relevant information and sharing knowledge as well. Information and Communication Technology (ICT) in 
agricultural extension can lead to the emergence of knowledgeable workers that will result in the realization of a bottom-up, demand driven paradigm for technology generation, assessment and refinement and transfer of new and modern technologies (Meera, 2004). A strong agricultural extension linkage complemented by flawless information flow enhanced by the effective use of ICTs will significantly boost agricultural production, productivity, income and improve rural livelihoods in developing countries (Arokoyo, 2005).

India has been experiencing major changes in agricultural extension system since the beginning of the $21^{\text {st }}$ century. The reforms included both demand and supply side measures. Information and Communication Technology (ICT) has great potential to revamp agricultural extension in big way. Up until now ICTs offered farmers a channel for communicating directly with distant technicians and experts, many farmers could wait months or years for an extension worker to provide technical advice and often that advice did not address their immediate concerns. ICT have great potential to increase access to advisory services to women, youth, even underprivileged sections of the society into remote and disadvantage areas.

Information and Communication Technology (ICT) has become a global tool often used by individuals, organizations, governments and intergovernmental organizations for personal or official activities. Its application cut across all fields of human endeavor like medicine, commerce, engineering, architecture, education, library services, and agriculture.

The use of information technology in the various sectors has increased rapidly across the world. In the agriculture sector, weather information systems, market information, insect-pest surveillance, internet, e-agriculture, agricultural information databases and other applications are used commonly in extension services.

Agricultural extension activities are nonformal in nature which helps farmers in improving their farming techniques and methods, increasing production efficiency and income, bettering their standard of living and lifting their social and educational standards. Agricultural extension plays the important role of providing a link between agricultural researches and farming communities to promote the adoption of new technologies and innovations by rural communities.

Compelling need for current Agricultural Knowledge and Information System (AKIS) by farmers in the era of climate change, world globalization and liberalization leading to agri-prenuership, the use of conventional communication channels become less effective. One way to address this is through the adoption of ICTs by both researchers and extension workers to transmit the relevant information to farmers in most effective and efficient way. Since the situation assessment survey of farmers conducted during the $59^{\text {th }}$ round of National Sample Survey (NSSO, 2005) provided valuable insights into reach of extension services across India. The public sector extension worker was a source of information for only 5.7 per cent of farmer households interviewed. Survey showed that 60 per cent of farm households did not access any information on modern technology.

The insufficient extension staff and financial constraints make agricultural extension more difficult. Study reveals that extension through contact is difficult as ratio of staffs to farmers varies widely from 1:300 in Kerala to 1:2000 in Rajasthan. The Situation Assessment Survey 2013 posited that traditional and modern ICTs (Newspaper, radio, television and internet) have also assumed important role 
as source of information of farmers. At the allIndia level, $41 \%$ of cultivating households accessed technical help from any source during reference period (July-December 2012). Public extension agencies, including extension workers, KVKs and SAUs were a source of information for around 10 percent of households (NSSO 2014)

At present use of information communication technology in agricultural extension system is far from satisfaction. Keeping in view the aforementioned facts the study was undertaken with the following objectives:

To assess the extent of use of information communication technologies by field functionaries

To identify the constraints in use of ICTs by field functionaries to manage agricultural information.

Field functionaries perception of consequences of not using the ICTs in present and near future

\section{Materials and Methods}

To collect the primary data on use of information and communication technologies by extension personnel to disseminate agricultural information, the respondents were selected with multistage sampling. The zone-1 of the country comprising five states (Delhi, Himachal Pradesh, Haryana, Jammu \& Kashmir and Punjab) was selected purposively having the food bowl of the nation and from selected zone Haryana was selected purposively due to direct access of the investigators. Hisar and Fatehabad districts of state were selected since being in the vicinity of CCSHAU, Hisar being nodal training centre for imparting monthly trainings to the extension personnel of state department of agriculture and easy access to the investigators. By census method all field functionaries i.e. Agricultural Development Officers (ADOs) and Block Agricultural Officers (BAOs) working in department of agriculture of both districts was selected. Accordingly there were 44 ADOs and 6 BAOs in Hisar and 40 ADOs in Fatehabad making thus total 90 extension personnel's data complete in all respect was considered for analysis and reporting. The data were collected with the help of well-structured and pretested schedule comprising the items for use of ICTs by field functionaries, constraints encountered by them and perception related to consequences of no use of these tools of communication. The descriptive statistical measures like frequency, percentage, mean, standard deviation, and rank order analysis were used to analyze the data to draw tangible inferences.

\section{Results and Discussion}

The results along with relevant discussion have been presented in prime heads as sociopersonal attributes profile, extent of use of information communication technologies by field functionaries, constraints faced by them and consequences perceived for no use of these tools.

\section{Socio-personal attributes profile of the extension personnel}

The Socio-personal attributes which were assumed to influence the use of ICTs have been included and presented in Table 1.

Perusal of Table 1 shows that majority of respondents $(66.66 \%)$ belonged to the middle age group (36-50 years) followed by 21.11 per cent young category (up to 35 years) and 12.23 percent to old age group (50 and above). In nut shell vast majority $(87.77 \%)$ belonged to productive age group with in depth knowledge and experience of extension. 
Table.1 Socio-personal attributes profile of the extension personnel

\begin{tabular}{|c|c|c|c|c|}
\hline $\begin{array}{l}\text { Sr. } \\
\text { No }\end{array}$ & Variables & Category & Frequency & $\%$ age \\
\hline \multirow{4}{*}{1.} & Age & & & \\
\hline & & Young (20-35 years) & 19 & 21.11 \\
\hline & & Middle (36-50 years) & 60 & 66.66 \\
\hline & & Old (more than 50 years) & 11 & 12.23 \\
\hline \multirow[t]{3}{*}{2.} & Gender & & & \\
\hline & & Male & 85 & 94.44 \\
\hline & & Female & 5 & 5.56 \\
\hline \multirow[t]{4}{*}{3.} & Educational status & & & \\
\hline & & B.Sc. Agri. & 33 & 36.67 \\
\hline & & M.Sc. Agri. & 33 & 36.67 \\
\hline & & Ph.D. & 24 & 26.66 \\
\hline \multirow{5}{*}{4.} & Job Experience & & & \\
\hline & & Less than 5 years & 28 & 31.12 \\
\hline & & $6-10$ years & 26 & 28.88 \\
\hline & & $11-15$ years & 15 & 16.67 \\
\hline & & More than 15 years & 21 & 23.33 \\
\hline \multirow[t]{4}{*}{5.} & $\begin{array}{l}\text { Rural-urban } \\
\text { background }\end{array}$ & & & \\
\hline & & Rural & 54 & 60.00 \\
\hline & & Urban & 12 & 13.34 \\
\hline & & Rural-urban & 24 & 26.66 \\
\hline \multirow[t]{5}{*}{6.} & Parental Occupation & & & \\
\hline & & Labour & 01 & 1.11 \\
\hline & & Farming & 42 & 46.67 \\
\hline & & Service & 40 & 44.45 \\
\hline & & Business & 07 & 7.77 \\
\hline \multirow[t]{3}{*}{7.} & $\begin{array}{l}\text { Specialized training } \\
\text { received on ICT }\end{array}$ & & & \\
\hline & & Received & 36 & 40.00 \\
\hline & & Not received & 54 & 60.00 \\
\hline \multirow[t]{9}{*}{8.} & ICT skills possessed & & & \\
\hline & & Data entry & 55 & 61.11 \\
\hline & & Internet & 79 & 87.77 \\
\hline & & MS Word & 69 & 76.66 \\
\hline & & MS Access & 20 & 22.22 \\
\hline & & MS Excel & 53 & 58.88 \\
\hline & & Power point & 54 & 60 \\
\hline & & Networking & 19 & 21.11 \\
\hline & & Programming & 11 & 12.22 \\
\hline
\end{tabular}


Table.2 Extent of use of information communication technologies by field functionaries

\begin{tabular}{|c|c|c|c|c|}
\hline $\begin{array}{l}\text { Sr. } \\
\text { No }\end{array}$ & Variables & Category & Frequency & $\begin{array}{r}(\mathrm{n}=90) \\
\% \text { age }\end{array}$ \\
\hline \multirow[t]{5}{*}{1} & Mobil phone & & & \\
\hline & & Advisory service & 75 & 83.3 \\
\hline & & Contingent service & 42 & 46.7 \\
\hline & & Farmers participation & 77 & 85.6 \\
\hline & & Awareness Campaign & 68 & 75.6 \\
\hline \multirow[t]{7}{*}{2} & Social media & & & \\
\hline & & WhatsApp & 75 & 83.3 \\
\hline & & Facebook & 52 & 57.8 \\
\hline & & Google+ & 21 & 23.3 \\
\hline & & Twitter & 11 & 12.2 \\
\hline & & Gab.ai & 0 & 0 \\
\hline & & You Tube & 26 & 28.9 \\
\hline \multirow[t]{11}{*}{3} & $\begin{array}{l}\text { Other } \quad \text { ICT } \\
\text { services }\end{array}$ & & & \\
\hline & & $\begin{array}{l}\text { E-mail advisory, awareness of new schemes, } \\
\text { internet or video clips for demonstrations or } \\
\text { dissemination of innovations }\end{array}$ & 42 & 46.7 \\
\hline & & Use the internet to search the information & 78 & 86.7 \\
\hline & & $\begin{array}{l}\text { Send or receive a text message (SMS)/voice } \\
\text { messages }\end{array}$ & 60 & 66.7 \\
\hline & & $\begin{array}{l}\text { Use a communication center/common service } \\
\text { center/village resource center (In case of no } \\
\text { internet access) }\end{array}$ & 47 & 52.2 \\
\hline & & $\begin{array}{l}\text { Use of computer for advisory work such as } \\
\text { expert system of different crops }\end{array}$ & 21 & 23.3 \\
\hline & & $\begin{array}{l}\text { Delivering any radio/TV talk on agricultural } \\
\text { topics }\end{array}$ & 20 & 22.2 \\
\hline & & Use of digital camera for diagnostic services & 40 & 44.4 \\
\hline & & $\begin{array}{l}\text { Use of digital camera for making farmer } \\
\text { participatory videos for further dissemination } \\
\text { of technologies }\end{array}$ & 50 & 55.5 \\
\hline & & $\begin{array}{l}\text { Use of LCD projector for showing films or } \\
\text { videos related to trainings or demonstration of } \\
\text { various new techniques and technologies }\end{array}$ & 29 & 32.2 \\
\hline & & $\begin{array}{l}\text { Use personal prepaid phone cards for mobile } \\
\text { phone for extension work or field work or } \\
\text { mobile phone provided by the department }\end{array}$ & 60 & 66.7 \\
\hline
\end{tabular}


Table.3 Constraints faced in use of ICTs by field functionaries

\begin{tabular}{|c|c|c|c|c|c|c|c|c|}
\hline \multirow{3}{*}{$\begin{array}{l}\text { Sr. } \\
\text { No. }\end{array}$} & \multirow{3}{*}{ Constraints } & & & & & & \multicolumn{2}{|c|}{$(n=90)$} \\
\hline & & \multicolumn{3}{|c|}{ Degree of seriousness } & \multirow{2}{*}{$\begin{array}{l}\text { Total } \\
\text { score }\end{array}$} & \multirow{2}{*}{$\begin{array}{l}\text { Mean } \\
\text { score }\end{array}$} & \multirow[t]{2}{*}{ SD } & \multirow{2}{*}{$\begin{array}{l}\text { Rank } \\
\text { order }\end{array}$} \\
\hline & & $\begin{array}{c}\text { Very } \\
\text { serious (2) }\end{array}$ & $\begin{array}{l}\text { Serious } \\
\text { (1) }\end{array}$ & $\begin{array}{c}\text { Not so } \\
\text { serious }(0)\end{array}$ & & & & \\
\hline 1. & $\begin{array}{l}\text { Inability of the extension personnel to } \\
\text { use ICT tools }\end{array}$ & $\begin{array}{c}24 \\
(26.7)\end{array}$ & $\begin{array}{c}40 \\
(44.4)\end{array}$ & $\begin{array}{c}26 \\
(28.9)\end{array}$ & 88 & 0.98 & 0.745 & XIII \\
\hline 2. & Lack of technological infrastructure & $\begin{array}{c}36 \\
(40.0)\end{array}$ & $\begin{array}{c}43 \\
(47.8)\end{array}$ & $\begin{array}{c}11 \\
(12.2)\end{array}$ & 115 & 1.27 & 0.667 & VI \\
\hline 3. & $\begin{array}{l}\text { High cost and lack of funds for } \\
\text { equipments }\end{array}$ & $\begin{array}{c}37 \\
(41.1)\end{array}$ & $\begin{array}{c}39 \\
(43.3)\end{array}$ & $\begin{array}{c}14 \\
(15.6)\end{array}$ & 113 & 1.25 & 0.708 & VIII \\
\hline 4. & $\begin{array}{l}\text { Not enough time to spend on } \\
\text { technology }\end{array}$ & $\begin{array}{c}11 \\
(12.2)\end{array}$ & $\begin{array}{c}36 \\
(40.0)\end{array}$ & $\begin{array}{c}43 \\
(47.8)\end{array}$ & 58 & 0.65 & 0.688 & XIV \\
\hline 5. & Lack of ICT experience and skills & $\begin{array}{c}27 \\
(30.0)\end{array}$ & $\begin{array}{c}44 \\
(44.9)\end{array}$ & $\begin{array}{c}19 \\
(21.1)\end{array}$ & 98 & 1.09 & 0.709 & $\mathrm{X}$ \\
\hline 6. & Lack of specialized trainings on ICT & $\begin{array}{c}44 \\
(44.9)\end{array}$ & $\begin{array}{c}35 \\
(38.9)\end{array}$ & $\begin{array}{c}11 \\
(12.2)\end{array}$ & 123 & 1.36 & 0.690 & II \\
\hline 7. & $\begin{array}{l}\text { Unsuitable \& incompatible, programs } \\
\text { or soft wares }\end{array}$ & $\begin{array}{c}24 \\
(25.6)\end{array}$ & $\begin{array}{c}43 \\
(46.7)\end{array}$ & $\begin{array}{c}24 \\
(27.8)\end{array}$ & 91 & 1.01 & 0.730 & XI \\
\hline 8. & No internet facility in village & $\begin{array}{c}39 \\
(43.3)\end{array}$ & $\begin{array}{c}36 \\
(40.0)\end{array}$ & $\begin{array}{c}15 \\
(16.7)\end{array}$ & 114 & 1.26 & 0.727 & VII \\
\hline 9. & No permanent office or space & $\begin{array}{c}41 \\
(45.6)\end{array}$ & $\begin{array}{c}35 \\
(38.8)\end{array}$ & $\begin{array}{c}14 \\
(15.6)\end{array}$ & 117 & 1.3 & 0.722 & IV \\
\hline 10. & $\begin{array}{l}\text { Clients' electricity use problem for } \\
\text { operating laptops/computers/projectors }\end{array}$ & $\begin{array}{c}27 \\
(30.0)\end{array}$ & $\begin{array}{c}36 \\
(40.0)\end{array}$ & $\begin{array}{c}15 \\
(16.6)\end{array}$ & 90 & 1 & 0.752 & XII \\
\hline 11. & $\begin{array}{l}\text { High cost of internet facilities in } \\
\text { villages }\end{array}$ & $\begin{array}{c}31 \\
(34.4)\end{array}$ & $\begin{array}{c}45 \\
(50.0)\end{array}$ & $\begin{array}{c}14 \\
(15.6)\end{array}$ & 107 & 1.18 & 0.681 & IX \\
\hline 12 & Lack of farmer's interest in ICT tools & $\begin{array}{c}41 \\
(45.6)\end{array}$ & $\begin{array}{c}37 \\
(41.1)\end{array}$ & $\begin{array}{c}12 \\
(13.3)\end{array}$ & 119 & 1.32 & 0.704 & III \\
\hline 13 & Lack of ICT trainers & $\begin{array}{c}36 \\
(40.0)\end{array}$ & $\begin{array}{c}44 \\
(47.8)\end{array}$ & $\begin{array}{c}10 \\
(12.2)\end{array}$ & 116 & 1.28 & 0.667 & V \\
\hline 14 & $\begin{array}{l}\text { Less knowledge of farmers about the } \\
\text { ICTs }\end{array}$ & $\begin{array}{c}40 \\
(44.4)\end{array}$ & $\begin{array}{c}44 \\
(48.9)\end{array}$ & $\begin{array}{c}6 \\
(6.7)\end{array}$ & 124 & 1.38 & 0.607 & I \\
\hline
\end{tabular}

Table.4 Consequences for not using ICTs presently and in the near future

\begin{tabular}{|c|c|c|c|c|c|c|c|c|}
\hline \multirow{3}{*}{$\begin{array}{l}\text { Sr. } \\
\text { No. }\end{array}$} & \multirow{3}{*}{ Consequences } & \multirow{2}{*}{\multicolumn{3}{|c|}{ Degree of Seriousness }} & & & \multicolumn{2}{|c|}{$(\mathrm{n}=90)$} \\
\hline & & & & & \multirow{2}{*}{$\begin{array}{l}\text { Total } \\
\text { score }\end{array}$} & \multirow{2}{*}{$\begin{array}{l}\text { Mean } \\
\text { score }\end{array}$} & SD & Rank \\
\hline & & $\begin{array}{c}\text { Very } \\
\text { serious (2) }\end{array}$ & $\begin{array}{l}\text { Serious } \\
\text { (1) }\end{array}$ & $\begin{array}{c}\text { Not so } \\
\text { serious }(0)\end{array}$ & & & & order \\
\hline 1. & $\begin{array}{l}\text { Loss of relevance, confidence } \\
\text { and credibility }\end{array}$ & $\begin{array}{c}26 \\
(28.9)\end{array}$ & $\begin{array}{c}57 \\
(63.3)\end{array}$ & $\begin{array}{c}7 \\
(7.8)\end{array}$ & 109 & 1.21 & 0.568 & VI \\
\hline 2. & $\begin{array}{l}\text { Isolates extension personnel } \\
\text { from his team }\end{array}$ & $\begin{array}{c}19 \\
(21.1)\end{array}$ & $\begin{array}{c}60 \\
(66.7)\end{array}$ & $\begin{array}{c}11 \\
(12.2)\end{array}$ & 98 & 1.08 & 0.570 & VII \\
\hline 3. & $\begin{array}{l}\text { Inefficient and inferior } \\
\text { extension and advisory service }\end{array}$ & $\begin{array}{c}30 \\
(33.3)\end{array}$ & $\begin{array}{c}51 \\
(56.7)\end{array}$ & $\begin{array}{c}9 \\
(10.0)\end{array}$ & 111.23 & 1.24 & 0.616 & IV \\
\hline 4. & $\begin{array}{l}\text { Loss of contact with timely } \\
\text { information }\end{array}$ & $\begin{array}{c}31 \\
(34.4)\end{array}$ & $\begin{array}{c}51 \\
(56.7)\end{array}$ & $\begin{array}{c}8 \\
(8.9)\end{array}$ & 113 & 1.25 & 0.607 & II \\
\hline 5. & Loss of competitiveness & $32(35.6)$ & $53(58.9)$ & $5(5.6)$ & 117 & 1.3 & 0.567 & I \\
\hline 6. & $\begin{array}{l}\text { Loss of extension management } \\
\text { efficiency }\end{array}$ & $\begin{array}{c}33 \\
(36.7)\end{array}$ & $\begin{array}{c}45 \\
(50.0)\end{array}$ & $\begin{array}{c}12 \\
(13.3)\end{array}$ & 111 & 1.13 & 0.667 & V \\
\hline 7. & $\begin{array}{l}\text { Problem of survival in career in } \\
\text { near future }\end{array}$ & $\begin{array}{c}34 \\
(37.8)\end{array}$ & $\begin{array}{c}44 \\
(47.8)\end{array}$ & $\begin{array}{c}13 \\
(14.4)\end{array}$ & 112 & 1.24 & 0.684 & III \\
\hline
\end{tabular}


Similarly 94.44 percent of the respondent field functionaries were male while 5.56 per cent were female illustrating in sufficient women extension personnel to support feminization of agriculture. Educational status of respondents clearly depicts that equal percentage (36.67) of the respondents were B.Sc. Agriculture i.e. graduation in agriculture which is minimum \& essential qualification for Agricultural Development Officer followed by postgraduation (M.Sc. in Agri.) followed by 26.66 per cent possessed the Ph.D. while none of them have done post-doctorate. The majority of respondents $(60.00 \%)$ had job experience up to 10 years followed by rural background clearly indicate better understanding of farming situation with incremental effect towards job commitment for farmers' welfare. ICT competency of the extension personnel indicated that only 40.00 percent of ADOs and BAOs received specialized training on ICT and remaining 60.00 percent did not receive any training despite that vast majority $(87.77 \%)$ of respondents possessed internet using skill followed by 76.66 percent MS Word skill, 61.11 per cent 'data entry, 60.0 per cent power point, 58.88 percent MS excel, 21.11 percent 'networking'. MS access 22.22 percent and finally programming 12.22 per cent. The possible reason might be use of smart phones especially social media along with on line official work nowadays.

Extent of use of information and communication technologies by field functionaries

Data pertaining to extent of use of information and communication technologies by field functionaries presented in Table 2 reveals that vast majority of the extension personnel used mobile phone for getting farmers participation $(85.6 \%)$ followed by advisory services $(83.3 \%)$, awareness campaign (75.6\%) and for the contingent service (45.6\%). The possible reason for less use in case of contingent service might be fewer occurrences of epidemic diseases and natural vagaries in the region. The use of social media indicated that 83.3 percent of the respondents were using Whats App for advisory work, dissemination of innovation, mobilization of farmers into various groups followed by Facebook (57.8\%), YouTube (28.9\%), Google+ $(23.3 \%)$ and Twitter by only $(12.2 \%)$ but no one used Gab.ai. probably ignorance of this media. It might be concluded that Whats App was most utilized social media followed by Facebook and YouTube. YouTube can be best utilized for universal, ultra-modern and complex technologies requiring demonstration through virtual world nowadays. Participatory videos on the You Tube can be used for farmer to farmer extension. The use of other ICTs further shows that vast majority $(86.7 \%)$ of the respondents used internet to search the new and useful information followed by sending or receiving text message (SMS)/voice messages (66.7\%), personal prepaid phone cards for mobile phone for extension work or field work or mobile phone provided by the department (66.7\%), digital camera for making farmer participatory videos for further dissemination of technologies (55.5\%), communication center/ common service center/village resource center (52.2\% in case of no internet access), e-mail advisory, awareness of new schemes, internet or video clips for demonstrations or dissemination of innovations (46.7\%), digital camera for diagnostic services $(44.4 \%)$, LCD projector for showing films or videos related to trainings or demonstration of various new techniques \& technologies (32.2\%), computer for advisory work such as expert system of different crops (23.3\%) and only 22.2 per cent used to deliver Radio/TV talk on agricultural topics. The findings highlight that digital cameras for diagnostic services, computer use for expert system and mass media are still to be exploited by field functionaries to increase outreach as well solution of plant and animal protection problems

\section{Constraints faced in use of ICTs by field functionaries}

The data regarding the constraints/factors limiting the use of ICTs by field functionaries have been presented in Table 3 depicts that less 
knowledge of farmers about the ICTs was very serious constraint followed by lack of specialized training on ICTs, lack of farmer's interest in ICT tools, no permanent office or space, lack of ICT trainers along with lack of technological infrastructure were serious constraints faced by field functionaries whereas, unsuitable and incompatible programmes or software, clients' electricity used for operating laptops, inability of the extension personnel to use ICT and spare time to spend on technology were not serious factors limiting the use of ICT by extension personnel in extension and farm advisory services.

Findings are supported by the findings of Ovwigho et al., (2009) which reported inadequate ICTs, lack of funds, high cost of computers and other ICTs, problem of internet connectivity, lack of supportive government policies and lack of on job trainings, low level of education of farmers etc.

Field functionaries perception of consequences of not using the ICTs in present and near future

The data pertaining to consequences due to no use of ICTs in present and future perceived by extension personnel have been presented in Table 4 depicts that loss of competitiveness very serious consequence followed by loss of contact with timely information, problem of survival in career in near future, inefficient and inferior extension and advisory service, loss of relevance, confidence and credibility, loss of extension management efficiency and isolation from his team were the other consequences. The findings emphasize that they had realized the significance of ICTs in growth of their profession. So government should make sincere efforts to develop infrastructure as well as competency of extension personnel in changing scenario of world.

\section{References}

Anonymous 2014. Situation Assessment Survey of Agricultural Households, January December, NSSO 70th Round (2013). National Sample Survey Organization Ministry of Statistics and Programme Implementation (MOSPI), Government of India.

Arokoyo, T. 2005. ICTs application in agricultural extension service delivery. In: Adedoyin, S.F (ed) Agricultural Extension in Nigeria. Ilorin: Agricultural extension society of Nigeria.

Karanja, K.B. (2014). Use of modern communication technologies among rural agricultural extension personnel to disseminate agricultural information: Case study of Machakos County. M.Sc. thesis in Agricultural Information and Communication Management. University of Nairobi

Meera. Shaik N. and Rao. D.U.M. 2004. Information and communication technology in agricultural development: A comparative analysis of three projects from India. Agricultural Research and Extension Network. Network paper No.135.

Ovwigho, B.O. Ifie, P. A. Ajobo, R. T. and Akor, E. I. (2009). The availability and use of information communication technologies by extension agents in delta agricultural development project, Delta State Nigeria. J. Hum Ecol, 27 (3): 185188.

\section{How to cite this article:}

Noor Agha, B.S. Ghanghas and Chahal, P.K. 2018. Use of Information and Communication Technologies by Extension Personnel to Disseminate Agricultural Information. Int.J.Curr.Microbiol.App.Sci. 7(04): 1369-1376. doi: https://doi.org/10.20546/ijcmas.2018.704.153 